\title{
Research on the Impact of Debt Structure on Corporate Performance of Listed Real Estate Companies
}

\author{
Zhengchao Zhang ${ }^{1,}$, , Tong Sun ${ }^{1, b^{*}}$ \\ ${ }^{1}$ College of Economics, Binhai Campus, Bohai University, Jinzhou City, Liaoning Province, china

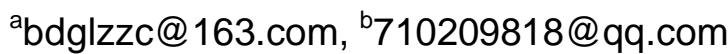 \\ ${ }^{*}$ Corresponding author
}

Keywords: Debt structure, Financial performance, Real estate

\begin{abstract}
Real estate companies are one of the most active forces in economic activities and occupy a large market share in China. Data of real estate listed companies from 2016 to 2018 are selected as samples to be listed on the Shanghai and Shenzhen stock exchanges. This paper studies by establishing panel data model, and used Stata15 software to empirically test different debt structures and whether debt levels affect performance. By processing the data, we can know that the higher the level of debt, the lower the company's performance, and performance will also improve as the proportion of short-term liabilities in the debt structure increases. The conclusion of this text shows that under the macro-economic background of deleveraging in China, real estate companies should reduce overall debt levels to reduce financial risks, and actively respond to national policies. In the structure of liabilities, the proportion of current liabilities should be appropriately increased to restrain the agent, reduce the risk investment behavior, and increase the business performance.
\end{abstract}

\section{Introduction}

As the tertiary industry, the real estate company has a high correlation with some upstream and downstream industries. The stability of its development will have a direct or indirect impact on these industries. Meanwhile, it is close to people's life, which is related to residents' family settlement and economic expenditure. Therefore, the healthy and steady development of the real estate company is one of the imperative conditions to promote national happiness and economic growth. It is an industry in great need of capital with a long development cycle and payback period, and its debt levels are generally high compared with other industries. Since the beginning of the 21st century, this industry has exerted more and more profound influence on the national macro-economy, and the state has also become more stringent on its supervision. As a result, the debt financing structure of real estate enterprises has also been profoundly affected. In 2015, the Chinese government put the supply-side reform proposal of "three cuts, one reduction and one repair" in an crucial position. The three cuts include cutting capacity, destocking and deleveraging. Among them, "deleveraging" has special significance [1]. The high debt level of the real estate company is easy to cause systemic risks. Therefore, the real estate industry deleveraging has become the key task of deleveraging. This paper will study the impact of debt level and debt structure on corporate performance and improve the operating performance of listed real estate by optimizing the debt level and structure.

\section{Literature Review and Research Hypothesis}

Debt is the normal business model of enterprises; it can make the enterprise capital turnover and play the role of tax shield tax deduction. That is to say, the interest that debt fund obtains can be deducted before paying tax. Therefore, many companies choose debt financing. But because the debt increases the uncertainty of the profit margin of the owner's equity, it will greatly increase the business risk. Based on the sample data of the real estate industry from 2009 to 2013, Shen Qian and $\mathrm{Xu}$ Min (2015) studied that asset-liability ratio and company performance presented an inverted u-shaped relationship [2]. Ren Murong and Feng Mingjing (2012) studied the data of 121 listed real 
estate companies from 2009 to 2011, showed that the asset-liability ratio was positively correlated with enterprise performance [3]. There has been a wealth of research on the impact of asset-liability ratio on performance. However, due to the differences in sample selection, time and mode.The research on the correlation between corporate debt level and corporate performance fails to reach a consistent conclusion. This paper only empirically studies the impact of debt level and structure on the performance of listed real estate companies, excluding industry differences. This paper thinks under the background of China's economy to leverage large, a high debt level will increase the risk of the enterprise and lead to a decline in the performance. Based on this, hypothesis 1 of this paper is proposed.

H1: Debt level is negatively correlated with performance

Jensen (1986) proposed in his study that restricting the excessive use of free cash corporate debt financing by the way of debt could prevent managers from excessive investment and reduce agency costs, which is called the role of debt financing in controlling the situation [4]. From the perspective of enterprise management, the existence of debt makes enterprises have repayment pressure. Compared with non-current liabilities, current liabilities are easier to play the role of debt governance. Current liabilities have a significant effect on supervision and constraint in the liability structure. If the proportion of current liabilities within one year is significant, the company will be faced with high repayment pressure, which will restrain the agent and reduce the risk of high risk, so as to reduce the agency cost and increase the company's operating performance. Based on this, hypothesis 2 of this paper is proposed.

$\mathrm{H} 2$ : Current debt ratio is negatively correlated with performance

\section{Study Design}

\subsection{Sample Selection and Data Sources}

This paper takes 129 listed real estate companies in Shanghai and Shenzhen from 2016 to 2018 as samples. The paper excluded listed companies with ST incomplete and outliers in the data to improve the accuracy and effectiveness of data analysis. Finally, 354 effective observations of 118 listed companies in three years were obtained. Data are all from the national Tai 'an research service center, flush, and other professional databases. Each financial index is directly or calculated according to the corresponding financial data.

\subsection{Variable Design}

\subsection{1 explained variables}

Operating performance refers to the economic benefits obtained by a company in operating activities. Financial performance includes many indicators, but from the perspective of shareholders and creditors, the company's profitability is the primary focus of their attention, and the return on total assets can be the most intuitive performance of the company's profitability. In this study, return on total assets is selected as the explanatory variable of performance. Expressed as a percentage of the average balance of total assets.

\subsection{2 explanatory variables}

Asset-liability ratio LV is the ratio of total liabilities to total assets, which is selected in this paper to reflect the debt level of enterprises.

Current liability ratio SLV, this is the ratio of current liabilities to total liabilities. It reflects how much a business needs to repay in the short term. This paper chooses this index to reflect the liability structure.

\subsection{3 explanatory variables}

The following control variables are introduced to make the results more robust. Company scale SIZE, the larger the size of the company, the more robust the enterprise, the stronger the risk tolerance, and the higher the value. Operating income growth rate, which is a good reflection of the change of revenue, is a measure of the development ability of enterprises. The shareholding ratio can reflect the ownership concentration degree of the enterprise. 
Table 1. Variable symbol and meter

\begin{tabular}{cc}
\hline Variable symbol & Variable meter \\
\hline ROA & Net profit/The average balance of total assets \\
\hline LV & Total indebtedness/Total assets \\
\hline SLV & Current liabilities /Total indebtedness \\
\hline SIZE & Ln (Total assets) \\
\hline TOP1 & The share ratio of the largest shareholder/Shares \\
\hline GROW & Revenue growth rate \\
\hline
\end{tabular}

\subsection{Model Design}

The hypothesis of this paper is studied by establishing two models. The first model of this paper verifies the impact of debt level on performance; the second model verifies the effect of debt structure on performance.

$$
\begin{gathered}
R O A_{i t}=\beta_{0}+\beta_{1} L V_{i t}+\beta_{2} S I Z E_{\mathrm{it}}+\beta_{3} G R O W_{i t}+\beta_{4} T O P 1_{\mathrm{it}}+\varepsilon \\
R O A_{i t}=\beta_{0}+\beta_{1} S L V_{i t}+\beta_{2} S I Z E_{\mathrm{it}}+\beta_{3} G R O W_{i t}+\beta_{4} T O P 1_{\mathrm{it}}+\varepsilon \\
(\mathrm{i}=1,2, \ldots \mathrm{N}, \mathrm{t}=1,2,3)
\end{gathered}
$$

\section{The empirical analysis}

\subsection{Descriptive statistical analysis}

Before the regression test, descriptive statistics were conducted on 354 data observed by real estate listed companies in three years. The statistical results are shown in Table 2.

Table 2. Descriptive statistics of variables

\begin{tabular}{cccccc}
\hline variable & The mean & $\begin{array}{c}\text { Standard } \\
\text { error }\end{array}$ & $\begin{array}{c}\text { The } \\
\text { minimum } \\
\text { value }\end{array}$ & $\begin{array}{c}\text { The } \\
\text { maximum }\end{array}$ & $\begin{array}{c}\text { Number of } \\
\text { observatio } \\
\text { ns }\end{array}$ \\
\hline ROA & 0.0284 & 0.0364 & 0.2971 & 0.2048 & 354 \\
\hline LV & 0.6521 & 0.1802 & 0.1001 & 0.9409 & 354 \\
\hline SLV & 0.6847 & 0.1724 & 0.1558 & 1 & 354 \\
\hline TOP1 & 0.3889 & 0.1565 & 0.0712 & 0.8065 & 354 \\
\hline Turns up & 0.2783 & 0.8350 & 0.8913 & 7.1091 & 354 \\
\hline The SIZE & 23.796 & 1.5125 & 19.1062 & 28.0554 & 354 \\
\hline
\end{tabular}

From table1, the average net profit ROA is $2.84 \%$. The debt level, namely the average LV is $65.21 \%$, and we can see that the debt level of real estate is generally high. The average value of SLV is $68.47 \%$, it shows that current liabilities account for more than half of the total debt level, and accounting for a relatively large proportion.

\subsection{Regression analysis}

In this paper, the OLS mixed effects model, fixed-effects model and random-effects model were selected for regression processing of panel data, and the Hausman test was conducted on the regression results. The results are as follows. 
Table 3. Regression results of asset-liability ratio on corporate performance

\begin{tabular}{cccc}
\hline & OLS & FE & RE \\
\hline lv & $0.0697 * * *$ & $0.288 * * *$ & $0.0932 * * *$ \\
\hline The size & $(0.0248)$ & $(0.0372)$ & $(0.0168)$ \\
\hline & $0.00519 * * *$ & $0.0271 * *$ & $0.00705 * * *$ \\
\hline Turns up & $(0.00170)$ & $(0.00852)$ & $(0.00207)$ \\
\hline & $0.00543 *$ & 0.00291 & $0.00494 * *$ \\
\hline top1 & $(0.00324)$ & $(0.00217)$ & $(0.00207)$ \\
\hline & 0.0200 & 0.00646 & 0.0217 \\
\hline Constant & $(0.0123)$ & $(0.0436)$ & $(0.0151)$ \\
\hline & $0.0590 * *$ & $0.431 * *$ & $0.0885 * *$ \\
\hline Observations & $(0.0282)$ & $(0.190)$ & $(0.0427)$ \\
\hline R - squared, & 354 & 354 & 354 \\
\hline
\end{tabular}

In model (1), the Hausman test result P-value is less than 0.01 , and the fixed effect model is adopted for analysis. The result shows that the coefficient on the debt level is negative and significant at the level of 0.01 , which is consistent with hypothesis 1 of this paper. In other words, the increase of the debt level of real estate companies will lower their performance.

Table 4. Regression results of current liability ratio on corporate performance

\begin{tabular}{cccc}
\hline & OLS & FE & RE \\
\hline slv & $0.0561 * * *$ & $0.0444 * *$ & $0.0533 * * *$ \\
& $(0.0151)$ & $(0.0193)$ & $(0.0120)$ \\
The size & 0.00132 & 0.00507 & 0.00115 \\
& $(0.00120)$ & $(0.00872)$ & $(0.00151)$ \\
Turns up & $0.00500 *$ & $0.00489 * *$ & $0.00497 * *$ \\
& $(0.00277)$ & $(0.00239)$ & $(0.00214)$ \\
top1 & 0.0162 & 0.0425 & 0.0170 \\
& $(0.0139)$ & $(0.0483)$ & $(0.0141)$ \\
Constant & 0.0490 & 0.101 & 0.0434 \\
& $(0.0317)$ & $(0.202)$ & $(0.0381)$ \\
Observations & 354 & 354 & 354 \\
R - squared, & 0.089 & 0.045 & 0.042 \\
\hline
\end{tabular}

In model (2), the Hausman test result P-value is greater than 0.01 , and the random effect model is adopted for analysis. The results show that the coefficient of short-term debt structure is positive and significant at the level of 0.01 , which is consistent with hypothesis 2 of this paper. In other words, performance will increase in real estate companies as the proportion of current liabilities in liabilities increases.

\section{Conclusions and recommendations}

Through empirical regression analysis on the panel data of the above 118 listed real estate companies for three years, the results are as follows, the level of debt is negatively correlated with corporate performance, while the current liability ratio is positive. The hypotheses in this paper have been verified. Through studying the effect of debt structure on corporate performance, this paper finds that the debt level and debt structure need to be adjusted and optimized to promote corporate value. Based on it, this paper proposes the following Suggestions:

In national macroeconomic regulation and control of environment, the real estate listed companies need to grasp the scale of debt when they choose to conduct financing through debt. Excessive debt level will lead to the risk of bankruptcy of the company, and the risk is greater than the benefits brought by the debt. This kind of behavior will reduce the company's performance. This paper holds that real estate enterprises should reduce their debt level by reducing their liabilities or improving their assets according to their actual operating conditions.

In the debt structure, increasing the current debt ratio can increase the cash flow of the enterprise 
in the short term. Meanwhile, due to the greater repayment pressure, it can also play a constraint role on the agent, reduce the enterprise's operating risk and increase the company's operating performance. But at the same time, the ratio should be reasonably increased. However, if it is blindly increased, the enterprise will go bankrupt due to excessive debt pressure of payment. The company ought to based on the actual situation of the enterprise, reasonable arrangement current debt ratio.

\section{References}

[1] Haidong Qi, Hao Liu, Wei Zhu, Research on deleveraging performance of over-indebted enterprises, Journal of accounting research, vol.12, pp. 3-11, 2018.

[2] Qian Shen and Min Xu, Empirical analysis on the impact of capital structure on corporate performance of listed real estate companies, Business economics research, vol.27, pp. 85-87, 2015.

[3] Murong Ren and Mingjing Feng, Analysis of the impact of capital structure on corporate performance of listed real estate companies, Journal of hunan agricultural university (social science edition), vol.04, pp. 55-61, 2012.

[4] Jensen m, A gency Costs of Free Cash Flow, Corporate Finance and Takeovers, American Economic Review, vol.2, pp. 323-330, 1986. 